\title{
АДАМ МІЦКЕВИЧ, ОЛЕКСАНДР ПУШКІН, ТАРАС ШЕВЧЕНКО: ВІЗІЯ НАЦІОНАЛЬНОЇ ІДЕНТИЧНОСТІ, МІСЦЕ В ЛІТЕРАТУРНОМУ КАНОНІ
}

\author{
Юрій Ковбасенко \\ Київський університет імені Бориса Грінченка, Київ, Україна \\ ORCID: 0000-0001-9832-7287
}

\begin{abstract}
Анотація. У статті розглянуто ключові моменти життєвих і творчих шляхів трьох центральних постатей слов'янських літератур: Адама Міцкевича (Польща), Олександра Пушкіна (Росія) і Тараса Шевченка (Україна). Акцент зроблений на засадничо-концептуальних (часто маловідомих) параметрах їхнього світогляду та творчості, зокрема - на візії національної i/або державної ідентичності, що ретельно ретушувалося літературознавством СРСР та соціалістичних країн. Зокрема, зроблено висновок про центральне місце творчості А. Міцкевича і Т. Шевченка відповідно в польському і українському літературних канонах, а також про певні “ідеологічні преференції” у випадку з “канонізацією” творчості О. Пушкіна в Росії.
\end{abstract}

Ключові слова: канон літературний; історична пам'ять; національна ідентичність; функції художньої літератури.

“Звів я пам’ятник свій. Довше, ніж мідь дзвінка, Вищий од пірамід царських, простоїть він..."

Горацій

Адам Міцкевич, Олександр Пушкін і Тарас Шевченко є трьома найбільшими поетами трьох сусідніх слов'янських народів, а їхній творчий доробок входить відповідно до польського, російського й українського літературних канонів. Це “а priori”, тож усе сказане нижче (з критичними роздумами включно) жодним чином не применшує високої оцінки їхнього мистецького хисту: усі вони вже звели собі “монументи” (“exegi monumentum") у пам'яті людства ${ }^{1}$, а їхні пам'ятники стоять у багатьох країнах світу.

1 Див.: Ю. Ковбасенко, «Надгробків иарських мармурові плити переживе потужний мій рядок» (авторефлексія геніїв на порозі Канону), "Studia Philologica" 2015, Вип. 4, c. 86-91; Той самий, "Сини вічності і слави»: мотив "ехеgi monumentum" у творчості В. Шекспіра та його наступників, “Ренесансні студії” 2016, Вип. 25-26, с. 188-201 [Інтернет джерело:] http://elibrary.kubg.edu.ua/id/eprint/16408/1/Y_Kovbasenko_Renessansny_ studiy_2016.pdf [доступ: 02.05.2019]. 
Проте в Україні чимдалі голосніше лунає думка, що пам'ятники О. Пушкіну слід демонтувати: "Ніхто не применшує ролі Пушкіна, світового класика, - йдеться, наприклад, у петиції Тернопільській міськраді від 07.06.2016, - але ми повинні чітко розуміти, що він у своїх творах вихваляв царську політику, спрямовану на приниження нашої нації, нашого прагнення до свободи"2. Схоже, що життя спростовує сподівання Пушкіна на те, що до його пам'ятника, принаймні в Україні, “не зарастет народная тропа” (“Я памятник себе воздвиг нерукотворный”, 1836). Здавалося б, такі суспільні настрої можна пояснити тим, що Україна (як і Польща) свого часу була колонією Росії, тож “постколоніальний монументопад" $є$ своєрідною компенсацією за століття національного приниження та гноблення. Проте в схожій ролі Україна перебувала й у Речі Посполитій, але з польською колонізацією українці Міцкевича не асоціюють, тож його пам'ятника з центру Львова прибирати ніхто не закликає.

Чому це так? Чи лише тому, що від Хмельниччини (1640-50-і pp.) литовсько-польська колонізація України - історичного центру Київської Руси - вже призабулася, а колонізація російська, протривавши від Переяславської ради (1654) аж до розвалу СРСР (1991), та ще й актуалізована окупацією Криму (2014) та загарбницькою “гібридною” війною РФ на Донбасі, для українців нині є значно болючішою темою? Чи справа ще й у специфіці творів і особистостях самих поетів? I чи не дав сам Пушкін певних підстав для того, аби Росія навіть у XXI ст. починала “гібридні війни” саме “артпідготовкою” мантр про велич його таланту: згадаймо всі ці численні й щедро фінансовані Москвою "Пушкінські дні”, "Росзарубіжцентри” та кафедри русистики його імені.

Це непросте питання вимагає відповіді зваженої та аргументованої, але в жоднім разі не емоційно-афектованої. Інакше можна легко потрапити до вже пострадянських пасток-софізмів на кшталт: “То що ви пропонуєте: геть колонізатора-Пушкіна і слава визволителю-Данте-

\footnotetext{
[Інтернет джерело:]: http://www.topnews.in.ua/ternopil/3654-ternopil-began-to-fightpetitions.html [Доступ: 02.05.2019]. Лишень я би сказав не “світового класика", а "російського класика", бо в світі значно відомішими за Олександра Пушкіна є Микола Гоголь, Лев Толстой і Федір Достоєвський. Ось авторитетна думка “батька теорії Канону”, професора Єльського університету Гаролда Блума: “...Я намагався представити національні канони крізь призму творчості їхніх иентральних авторів: Чосера, Шекспіра, Мільтона, Вордсворта, Діккенса в Англії, Монтеня та Мольєра у Франції, Данте в Італії, Сервантеса в Іспанії, Толстого в Росії, Гете в Німеччині, Борхеса та Неруди в Іспанській Америці, Вітмена та Дікінсон у США” [Блум, 6].

3 Автор цих рядків був присутнім при поваленні пам'ятника Леніну в Києві 08.12.2013 року, під час Революції Гідності, яке й започаткувало всеукраїнський “Ленінопад”. Чи почнеться "Пушкінопад"? - that is the question.
} 
сові ${ }^{4} ? ”$. Тож пошуки саме такої відповіді й обумовили звернення до постатей усіх трьох національних геніїв, котрі жили й творили в одному часопросторі, значною мірою впливаючи один на одного.

Отже, Адам Міцкевич (1798-1855), Олександр Пуикін (1799-1837) i Тарас Шевченко (1814-1861) були сучасниками та громадянами Російської імперії. Поляк і росіянин, як шляхтичі, закінчили відповідно Віленський університет (1819) і Царськосільський Ліцей (1817). При цьому провінціал Міцкевич, за оцінками навіть сучасників-росіян, був краще освіченим і талановитішим за "столичного" Пушкіна. Шевченко ж народився кріпаком, тож початкову освіту здобував переважно самотужки, аж доки не зробив карколомної кар'єри, ставши студентом-стипендіатом Петербурзької академії мистецтв, учнем знаменитого Карла Брюллова (котрий, до речі, бував удома і в Пушкіна, і навіть у Миколи I). Від кріпака з українського села до столичного академіка - таким був тріумфальний шлях Шевченка. Попри відзначену різницю в їхньому походженні, їхні творчі доробки, епістолярій, мемуарна література засвідчують надзвичайно високий рівень освіти та інтелекту всіх трьох митців.

Усі вони сповідували ліберальні ідеї і перебували, хоча й різноюмірою, в опозиції до царату, тож ризикували (передовсім, українець і поляк) своєю свободою і навіть життям. 3 другого боку, "небезпечне вільнодумство” в пригніченому російському соціумі сприяло їхньому літературному успіху: вони були водночас як кумирами передової, так і ворогами реакційної частин суспільства, тому їхні твори уважно читали як перші, так і другі, а широка читацька аудиторія $\epsilon$ необхідною умовою популярності письменника. Росіянин Віссаріон Бєлінський пояснював цю парадоксальну ситуацію українцю (імперським сленгом - “малоросу”) Миколі Гоголю так: "Ви... не зовсім добре розумієте російську публіку. Її характер визначається станом російського суспільства, де киплять і рвуться назовні свіжі сили, але, пригноблені важким гнітом, не знаходячи виходу, породжують лише сум, нудьгу, апатію. I в самій лише літературі, попри татарську [sic! - Ю. К.] цензуру, є ще життя й поступ. Ось чому звання письменника в нас таке шановане, чому в нас такий легкий літературний успіх, навіть за невеликого таланту. Титул поета, звання літератора в нас давно вже переважило мішуру еполетів і строкатих мундирів. І ось чому в нас особливо нагороджується загальною увагою будь-який так званий ліберальний напрямок, навіть попри бідність таланту..."

\footnotetext{
4 Дантес - французький емігрант-рояліст, офіцер російської гвардії, котрий 27 січня (08 лютого за новим стилем) 1837 р. на дуелі біля Чорної річки смертельно поранив Олександра Пушкіна.

5 В. Г. Белинский, Лист від 15.03.1847, [в:] Той самий, Литературное наследство, т. II, Москва 1950, с. 571-581.
} 
Усі три поети писали антимонархічні твори. Наприклад, сповнені ідеологем Американської і Французької революцій рядки Міцкевича звучать як гімн Демократії: "Над світом над Новим сяйне зоря свободи, / Добро, наука й честь зійдуться в світлі згоди. / I пута деспотів зламаються в неволі, / До неба золотий зведеться Капітолій, / I перед ним народ впаде в земнім поклоні, / А берлом Люд-Король зрівняє всіх в законі, / Тиранів геть змете й Європу, що страждає, / Із іскри вільної вогнем новим осяе" (пер. Михайла Литвинця). В унісон лунають рядки Пушкіна: "Товарищ, верь, взойдет она, / Звезда пленительного счастья. / Россия вспрянет ото сна, / И на обломках самовластья / Напишут наши имена" (К Чаадаеву, 1818).

Шевченко теж умів писати пафосно, в стилі Біблії: “...Буде бите / Царями сіянеє жито! / А люде виростуть. Умруть / Ще не зачатиє царята... / I на оновленій землі / Врага не буде, супостата, / А буде син, і буде мати, / I будуть люде на землі" (I Архімед, i Галілей..., 1860). Але антимонархічні мотиви український поет зазвичай утілював гостро-радикально. На відміну від абстрактно-романтичної символіки поляка й росіянина (“зоря свободи”, “вільна іскра”, “новий вогонь”, “звезда пленительного счастья"), в українця переважають дошкульні анімалістичні паралелі: слуги царя - це його $n c u$, тож Російська імперія - псарня. Римування семантично й стилістично антитетичних лексем "цар/псар" стає в нього домінантою: “...Слава! Слава! / Хортам, і гончим, і псарям, / I нашим батюшкам-циарям / Слава!” (Кавказ, 1845) або: “О люди! люди-небораки! / Нащо здалися вам uарi? / Нащо здалися вам ncapi? / Ви ж таки люди, не собаки!..." (О люди! люди-небораки!.., 1860).

Заперечувати абсолютизм поети вміли лаконічно, буквально одним (але сугестивно-символічним) словом. Так, Міцкевич, як геніальний митець і ментальний європеєць ${ }^{6}$, тонко відчув емблематичний для Росії потенціал лексем функціонально-семантичного поля 'знаряддя тортур, поневолення' (“батіг”, “кнут”, “бич” та ін.) і активно вживав його для засудження російської деспотії. Ось сповнений їдкого сарказму перелік вуличних вивісок Петербурга з віршів поляка: “...А написів, таблиць! Ізпід карнизів / Говорять букви й звуки різних мов, / Ти начебто у Вавілон

\footnotetext{
6 На експертній раді з проблем літературної освіти в АПН СРСР (1988) я чув виступ представника середньоазійської радянської республіки про те, що їхнім школярам категорично не можна пропонувати деяких творів, які успішно вивчаються в європейській частині Радянського Союзу. Як приклад він навів вірш Миколи Некрасова: "Вчерашний день, в часу шестом / Зашел я на Сенную; / Там били женщину кнутом, / Крестьянку молодую...”, пояснивши, що учні-азійці не розуміють концепції твору, оскільки слово “кнут" (“батіг”) в їхній рецепції входить до позитивнооціночного семантичного поля “сміливий, сильний юнак”, а не до пейоративного поля “тиранія, деспотизм”, як гадали укладачі програм.
} 
прийшов... / Ще написи великої ваги: / “Дитячі іграшки” і “Батоги”...” (Дзяди). Або той-таки сарказм щодо російського офіцера, етнічного німця, в якому “мирно уживались" непоєднанні риси: садизм на службі із позірним захопленням "сентиментальним Шіллером" у у вільний від тортурування солдатів час: “...ІІх офіцери? Тут сентиментальна / Фігура, німець. Шіллера чита, / Бичем б’є жовнірів уздовж хребта...” (Дзяди). Позиція Шевченка напрочуд схожа: “...Просвітились! та ще й хочем / Других просвітити, / Сонце правди показати / Сліпим, бачиш, дітям!.. / Все покажем! тілько дайте / Себе в руки взяти. / Як і тюрми муровати, / Кайдани кувати, / Як і носить!.. і як плести / Кнути узловаті” (Кавказ, 1845).

Пушкін теж писав, що бачить "везде бичи, везде оковы", проте це була швидше данина абстрактній романтичній риториці, аніж засудження жахливих російських реалій, що їх було більш ніж досить. Наприклад, за доведення до абсурду запровадженої ще Петром I "палочної дисципліни" (засуджувати почали до 6000 ударів шпіцрутеном, хоча людина помирала ще до 1000 ударів), цар Микола I (рос. "Николай Павлович", народна вимова "Николай Пальч") отримав прізвисько "Николай Палкин”. До речі, саме так називається стаття Льва Толстого, де $є$ не “глянсовані", , а реальні 9 факти подавлення росіянами польського Листопадового повстання $1830-31$ років $^{10}$.

Отже, Міцкевич і Шевченко заперечували монархію як таку (передовсім в іiі російському, ординсько-деспотичному вияві), натомість Пушкін обурювався не царатом як таким, а лише тими конкретними

\footnotetext{
7 Схожа ситуація описана в оповіданні Льва Толстого После бала, де той самий офіцер, котрий викликає симпатії на балу, “сентиментально” танцюючи зі своєю донькою, після балу (звідси назва твору) виявляється садистом, котрий спокійнісінько керує проведенням солдата крізь стрій катів із закривавленими шпіцрутенами.

8 У сучасних російських публікаціях підкреслено, що перед початком придушення Листопадового повстання Микола І видав красивий маніфест (12 грудня 1830), де закликав росіян “виявити до поляків правосуддя без помсти” див.: Ю. Лебедев, “Клеветникам России” А. С. Пушкина, “Литература в школе” 2010, № 5, с. 14].

9 “Спокій і відсутність каяття були в нього (російського солдата, що придушував Листопадове повстання - Ю. К.) і щодо військових жахів, у яких він брав участь і яких багато бачив... у Польщі. Він розповів про вбитих дітей, про смерть від голоду й холоду полонених, про вбивство багнетом хлопчика-поляка, який притулився до дерева" (Л. Н. Толстой, Николай Палкин, [в:] Той самий, Собрание сочинений в 22 m., т. 17, Москва 1984, с. 220-222).

10 Повстання почалося у Варшаві наприкінці листопада 1830 р. Його причиною стало порушення Миколою I конституції 1815 р. Поляки здобули низку блискучих перемог над росіянами (під Сточком, Вавром, Грохувом, Вельким Дємбом), але через чвари в керівництві та неузгодженість дій зазнали поразки під Остроленкою. Російський каральний корпус під керівництвом фельдмаршала I. Паскевича після дводенного штурму 06-07.09.1831 узяв Варшаву. Більшість польських підрозділів вийшла з Польщі через австрійський і пруський кордони.
} 
вчинками царів, які зачіпали особисто його, Пушкіна ${ }^{11}$. Саме тому він міг царями як обурюватися, так і лестити їм, що було геть неприйнятним для Міцкевича й Шевченка, котрі на вівтар боротьби з деспотизмом поклали власні життя ${ }^{12}$.

Об'єднує всіх трьох поетів ще й їхня близкість до антимонархічних таємних товариств. Участі Міцкевича у віленських студентських гуртках “філоматів" (“любителів наук”) і “філаретів” (“любителів чеснот”) або членству Шевченка в Кирило-Мефодіївському братстві присвячені цілі томи. Ще більше в СРСР писалося про близькість Пушкіна до декабристів. Але якщо поляк і українець до цих товариств таки належали, то Пушкіна ані в Молдавії та Україні (“Південне товариство"), ані в Петербурзі ("Північне товариство") декабристи до своїх лав так і не прийняли. Це $\epsilon$ фактом, хай би як його інтерпретували. А інтерпретацій чимало. Пишуть, що декабристи оберігали талант Пушкіна для Росії на випадок свого провалу. Водночас існує й протилежна думка: “Суворі політичні наставники Пушкіна відчували, що... від нього можна очікувати неочікуваного. Вони захоплювалися поезією Пушкіна, проте лише частково, заперечуючи певні ї̈ сторони. І в самому поеті вони б воліли бачити більше тієї односторонності, без якої, на їхню думку, не існує й громадянського героїзму", тому щодо нього в них існувала "певна настороженість" 13 . На Сенатській площі в Петербурзі, де 14 грудня (рос. "14 декабря”, звідси “декабристы”) 1825 р. відбувся антимонархічний збройний виступ, Пушкіна не було. Це теж факт, хай би як його не інтерпретували.

Ситуація з неучастю емігранта-Міцкевича в Листопадовому повстанні теж неоднозначна. Одні дослідники (М. Яструн та ін.) стверджують, що кордону Російської імперії він не перетинав. Другі (М. Стріха та ін.) пишуть, що в серпні 1831 р. Міцкевич із підробним паспортом, нелегально перетнув кордон, аби долучитися до повстання, але назустріч уже рухалися на еміграцію колони розбитих поляків...

Усі три поети потрапляли в опалу до російського царату. Для поляка й українця наслідки їхньої вільнолюбної, антидеспотичної (отже - антиросійської) позиції були схожими. За участь у діяльності “філаретів” i “філоматів” Міцкевича заарештували (1823) і через півроку вислали до

\footnotetext{
11 Про обурення Пушкіна таємним прочитанням царедворцями їхнього 3 дружиною приватного листування див.: Ю. Лотман, Александр Сергеевич Пушкин. Биография писателя, Ленинград 1982, с. 205.

12 Шевченко на засланні підірвав здоров'я й невдовзі після звільнення помер, а Міцкевич сконав від холери (чи був отруєний?) у Константинополі, де готував польсько-український полк для боротьби проти Росії в Кримській війні 1854-55 (до слова, ганебно програної Росією, через що, за деякими джерелами, Микола I вкоротив собі віку, а в Севастополі й нині стоїть “Пам'ятник затопленим кораблям”).

13 Ю. Лотман, цит. праця, с. 91-92.
} 
“віддалених від Польщі губерній”. Як усі небезпечні для Росії політичні злочинці (згодом туди етапували й Тараса Шевченка), по вирок Міцкевич прибув до Петербурга, де зблизився з декабристами Кіндратом Рилєєвим і Олександром Бестужевим. Саме їх - першого вже повішеного, другого зісланого до Сибіру - поет згадає в Дрездені, в забороненому в Росії додатку до ч. III поеми Дзяди - вірші До приятелів-москалів (Do przyjaciót Moskali). Із Петербурга Міцкевич попрямував до Одеси, відвідавши Чернігів, Київ, Слисаветград, а звідти - до Криму, де збирав матеріал для Кримських сонетів. У жовтні 1825 р. він прибув до Москви, де познайомився й заприятелював із Пушкіним. А в березні 1829 р., дивом отримавши закордонний паспорт, виїхав до Свропи, звідки додому вже не повертався. Та, власне, й “дому” вже не було, бо за участь його рідного брата Францішека в Листопадовому повстанні їхній родинний фольварок Заосся під Новогрудком (нині Білорусь) росіяни конфіскували й пустили 3 молотка.

Шевченка ж за участь у Кирило-Мефодіївському братстві та антиколоніальні вірші заарештували (17.04.1847) й етапували до Петербурга. Поета звинуватили в написанні його рідною, українською мовою (імперським сленгом - “малороссийским наречием") віршів, із якими “могли посіятися й згодом укоренитися думки про вигадане блаженство часів Гетьманщини, про щастя повернути ті часи й про можливість Україні існувати як окремій державі". Російські слідчі правильно оцінили небезпеку Кирило-Мефодіївського братства для їхньої імперії: до негайного збройного виступу його діяльність не призвела б, але посіяні зерна в майбутньому призвели б до самовизначення українців як окремої державної нації (як бачимо, так воно й сталося спочатку 1918-го, а згодом і 1991-го рр.), а слідом за українцями захотіли б суверенітету й інші поневолені росіянами народи, в тому числі і поляки. Не подобався жандармам і зміст творів Шевченка (на той час він уже написав свій "Opus magnum" - збірку Кобзар $\left.{ }^{14}\right)$. Тож із Петербурга на довгі 10 років його зіслали рядовим на Арал, до дикого Оренбурзького краю. Геніальному українському поетові й художнику ще й “височайше" заборонили писати й малювати, що для Митця є витонченою тортурою. Своє заслання Шевченко влучно порівняв із вигнанням Овідія з Риму: “Август-язичник, зіславши Назона до диких гетів, не заборонив йому писати й малювати. А християнин $\mathrm{N}$ (Микола І. - Ю. К.) заборонив мені і те, й друге. Обидва кати...” (Що-

14 До першого видання Кобзаря (1840) увійшло 8 поезій: Думи мої, Перебендя, Катерина, Тополя, Думка, До Основ'яненка, Іван Підкова, Тарасова ніч; окремо вийшли Гайдамаки (1841) і Гамалія (1844). Крім того, світ побачили: Розрита могила (1843), Сон (“У всякого своя доля... ”) (1844), Великий льох, Кавказ (його Шевченко передав Міцкевичу до Парижа), І мертвим і живим..., Холодний Яр, Заповіт (1845). 
денник, 19.06.1857). Звільнили Шевченка аж 1857 р., вже після смерті Миколи I, із заслання він повернувся інвалідом й невдовзі помер.

Про т. зв. “заслання” Пушкіна писалося дуже багато, адже в СРСР 3 нього ліпили образ “співця свободи” та непримиренного ворога царату. Насправді ж факти є такими: як дрібного чиновника, в порядку службового стягнення за “вірші, на гідні його посади” його відрядили на Південь Російської імперії (1820), до нинішніх теренів Молдови й України (т. зв. “південне заслання"), а 1824 р. - до родового маєтку Ганнібалів у с. Михайлівському (т. зв. “північне заслання”). На Півдні він, як згодом Шевченко, порівняв себе з Овідієм. Проте українець мав для цього незрівнянно вагоміші підстави: дикі Томи = дикий Арал; гети, чиєї мови не знав римлянин = казахи, чиєї мови не знав українець; пожиттєве заслання автора творів, небажаних для Октавіана Августа = 10-річне заслання автора творів, небажаних для Миколи І... Натомість Пушкін не стільки був жертвою сваволі тирана, скільки виконував роль "романтичного вигнанця", такого собі “північного Байрона". Цим він ніби вивищувався як у самооцінці, так і в суспільній думці: “Ототожнення себе з Овідієм, а Олександра I - із лукавим деспотом Августом, котрий ховав жагу помсти за маскою величі, давало Пушкіну і життєву роль, і масштаб для виміру власної особистості. Поет, якого переслідує Влада, опиняється 3 нею на одному рівні (1825 року Пушкін мав на увазі саме це, коли писав, що Наполеон удостоїв Ж. Сталь гоніння)... Для Олександра I (як згодом і для Воронцова) Пушкін був лише нікчемним дрібним чиновником, котрий отримав урядове стягнення. Натомість сам собі та своїм читачам Пушкін пропонував іншу інтерпретацію: він - Овідій, поет, гнаний тираном. Далі починалося протиставлення. Овідій - малодушний і зманіжений південний співак, автор елегій і еротичної поезії - благав Октавіана Августа про прощення. Натомість сам Пушкін, “суворий слов'янин, він сліз не проливав ..., Октавію - в сліпій надії - / Лестивих од він не співав..."15.

Виникає питання: ну добре, нехай би Пушкін (хоч і безпідставно) порівняв себе з римським вигнанцем, але навіщо було при цьому ще й принижувати самого Овідія? Адже, по-перше, римлянин, провівши на засланні цілих 10 років (як згодом Тарас Шевченко на Аралі), до Риму так і не повернувся, а помер на чужині. Натомість сам Пушкін, провівши у південному відрядженні (“засланні”) чотири роки, дякувати Богу, повернувся додому при доброму здоров'ї. По-друге, Овідій “молебнів лестощів" Августові ніколи й не співав. У своїх Скорботних елегіях (Tristia) він питав про причини свого вигнання (а вони невідомі й донині) та скаржився на незвичні для римлянина умови життя у холодних варварських

15 Ю. Лотман, Александр Сергеевич Пушкин. Биография писателя, цит. праця, с. 68. 
Томах. “Нащо на муки мені край цей відкрито сумний?” - ось лейтмотив Овідія. Можливо, така позиція Пушкіна була обумовлена його бажанням вивищитися на тлі приниження римського генія? А, може, браком освіти (“мы все учились понемногу чему-нибудь и как-нибудь...”)? Та в обох випадках це не є позитивним.

Але найцікавіше те, що сам “суворий слов'янин” Пушкін своїм імператорам таки лестив, причому, обом: як Олександрові I (“...Ура, наш царь! Так! Выпьем за царя... / Он взял Париж, он основал лицей” / 19 октября 1825 года/), так і Миколі I (“...Каков государь? Молодец! Того и гляди, - писав О.Пушкін у листі до П. В'яземського 05.11.1830, - что наших каторжников простит - дай бог ему здоровье"). На жаль, мстивий і злопам'ятний Микола I (“молодець-государь”) жодного 3 декабристів так і не вибачив, як згодом не вибачив і Шевченка, хоча й отримував відповідні клопотання. А ось Пушкіна, навпаки, він обласкав і зробив своїм придворним. I, щойно надягнувши смішну для його віку камер-юнкерську ліврею (1834), “суворий слов'янин” Пушкін пафосно написав: “... Для власти, для ливреи / Не гнуть ни совести, ни помыслов, ни шеи... Вот счастье!” (Из Пиндемонти, 1836). Звісно, можна висунути припущення, що він нарешті “прозрів" щодо придворних лише тоді, коли “вступил в этот свет, завистливый и душный для сердца вольного и пламенных страстей” (М. Лермонтов, Смерть поэта). Як можна сказати, що рядки "волхвы не боятся могучих владык, а княжеский дар им не нужен” (Песнь о Вещем Олеге, 1822) жодним чином не пов'язані з його, Пушкіна, особистим астрономічним боргом Миколі I розміром 45000 рублів золотом (для порівняння: Шевченка з кріпацтва викупили за 2500 рублів, а молодий здоровий кріпак разом із усією його сім'єю коштували тоді до 400-500 рублів)... Звісно, смерть 37-річного талановитого Пушкіна $\epsilon$ трагедією. Та факт залишається фактом: беспосередньо від імперської репресивної машини з-поміж трьох поетів найбільше постраждали Тарас Шевченко і Адам Міцкевич.

А завдяки яким свойм параметрам творчість Міцкевича, Пуикіна і Шевченка увійила до літературних канонів? Звісно, найпершою умовою цього $€$ письменницький талант, що ним Бог щедро наділив усіх трьох поетів. Їхня творчість відзначалася надзвичайно широким жанрово-тематичним діапазоном (інтимна, громадянська, філософська лірика, драматургія, проза, переклади з різних мов світу, літературно-критичні статті тощо) та корелювала 3 тогочасними літературними мейнстримами: вони починали як романтики і поступово рухалися в бік реалізму, що відповідало логіці розвитку європейського літературного процесу (схожим шляхом ішли Стендаль, Оноре де Бальзак, Віктор Гюго, Чарльз Діккенс, Микола Гоголь та ін.). У їхніх творах $є$ безліч ремінісценцій і алюзій, оскільки вони спиралися на інтелектуально-естетичний досвід людства. 
Водночас "своєрідною міткою оригінальності, котра може забезпечити твору місце в каноні, є його незвичність (strangeness)" 16 , а Мiикевич, Пушкін і Шевченко були сміливими новаторами, часто буквально шокуючи сучасників незвичністю своєї творчості. Так, Міцкевичеву Оду до молодості (1827) через новизну іiі поетики сучасники просто не зрозуміли, і лише його друг Францішек Малевський переконував очільників товариств “філоматів” і “філаретів” Томаша Зана і Яна Чечота: “Оце порив! Оце думка! Оце поезія!... На цукерковій обгортці такого не прочитаєш... Жоден поляк так іще не писав" ${ }^{17}$. Міцкевич збагатив польську поезію, яка до того перебувала в річищі естетики класицизму, новими темами, ритмами, образами й навіть лексикою, яка часто дратувала тогочасний читацький загал: "У салонах томик Міцкевича зустрінуто сміхом і обуренням. Вітчим Словацького, пан Бекю, повторював “а киш, а киш” із таким акцентом та виразом обличчя, що все товариство вибухало сміхом. Юний Юліуш розплакався із сорому. Осінський і Козм'ян кпили й собі 3 незрозумілих для них або простонародних виразів цієї нової поезії. А сила цих творів була якраз у мові, в лексиці не книжній, а живій..."18.

Пушкін теж належав до “новаторів”, які вели справжні літературні війни проти чавунно-неповороткого стилю “архаїстів”. Він також шокував тогочасний російський читацький загал нечуваною доти легкістю вірша, його наближеністю до живої говірки та сміливим вживанням варваризмів (“но панталоны, фрак, жилет - всех этих слов на русском нет"). Художнє новаторство Пушкіна - тема окремої грунтовної розмови, оскільки його творчість $є$ цілою добою російської літератури й мови.

А вже про новаторство Шевченка можна писати безкінечно. Якщо Міцкевич і Пушкін були творцями польської і російської сучасних літературних мов, то Шевченко є ще й творцем самої української нації, національним пророком. "Шевченко своєю національною самосвідомістю $\epsilon$ геній, а своєю незмірною вагою, значенням у справі нащіонального відродження свого рідного краю є 3'явищем феноменальним, єдиним, може, на світі - писав Борис Грінченко. В той час, як його попередники ледве насмілювались у своїх творах згадувати про вкраїнську самостійність, а коли й згадували, то розуміли іiі не як самостійність нації, а як самостійність (дуже невелику) частини «єдиного и неделимого русского народа», самостійність з ласки сього «єдиного» народу, чи тобто «старшого брата», Шевченко виразно становить у своїх творах самостійність нашу як нації" 19 .

Г. Блум, Західний канон: книги на тлі епох, пер. Р. Семків, Київ 2007, с. 9.

М. Яструн, Мічкевич, пер. Д. Андрухів, Київ 2008, с. 48.

Там само, с. 108-109.

19 Б. Грінченко, Листи з Украӥни Наддніпрянської, [Інтернет посилання:] http://litopys. org.ua/drag/drag204.htm [доступ: 03.05.2019]. 
Отже, з одного боку, творчість усіх трьох поетів інтегрована до тогочасних літературних мейнстримів, але, з другого боку, усі вони були сміливими трансформаторами традицій, реформаторами й новаторами.

Усі три поети були володарями дум своєї епохи, але кожен з-поміж них мав “свою правду", власну історіософічну візію иляхів розвитку свого народу. Міцкевичева правда пов'язана з мрією про відродження 3 розірваних шматків єдиної могутньої Польщі, гідної колишньої величі Речі Посполитої, за його висловом, “гордості наших предків, нині нашої туги" 20 , зокрема й про звільнення ії від російського гніту. Ним написана Книга народу польського і польського пілігримства (що згодом прислужилася Миколі Костомарову для написання головного ідеологічного документа Кирило-Мефодіївського братства - Книги буття українського народу, - тож у Російській імперії ідеї свідомих поляків і українців були суголосними). І Міцкевича правда перемогла - після усіх численних поділів і паювання між сусідами нині Польща єдина й незалежна.

Шевченко теж мріяв про повернення Україні міжнародного авторитету та слави могутніх Київської Русі та Гетьманщини (“славних прадідів великих"), про звільнення ії від іга Росії та й від будь-якого іга (на його думку, українці не повинні бути ані “гряззю Москви”, ані “Варшавським сміттям”): "Встане Україна. / І розвіє тьму неволі, / Світ правди засвітить, / I помоляться на волі / Невольничі діти!..” (Стоїть в селі Сyботові, 1845). Шевченкова правда теж перемогла: нині єдина й незалежна Україна відбиває російську агресію, бо не хоче назад до Російської імперії (хай як би та не називалася).

Натомість погляди Пушкіна на долю поляків і українців були діаметрально протилежними. Віддавши данину модній просвітницькій риториці про "свободу, рівність, братерство", він тлумачив ці поняття 3 великодержавних позицій Російської імперії (“Руси великой”), де, на його переконання, мусили общинно жити всі нації, “всяк сущий в ней язык: и гордый внук славян, и финн, и ныне дикой тунгус, и друг степей калмык”21. При цьому “гордый внук славян” міг бути лише росіянином, а не поляком, українцем чи білорусом, які для Пушкіна всі були "росіянами” (“мало-росами”, “біло-росами”, “ново-росами”), себто асимілянтами Російської імперії. На його думку, “славянские ручьи” повинні були “слиться в русском море”). (Клеветникам России, 1831). А ось право народів на самовизначення, на будь-який власний національний

\footnotetext{
20 М. Яструн, Міиякевич, цит. праця, с. 562.

213 ним імпліцитно полемізував Шевченко в поемі Кавказ: на формулу Пушкіна “всяк сущий в ней язык” він саркастично відповів: “...ОД молдаванина до фінна / На всіх язиках все мовчить, / Бо благоденствує!".
} 
патріотизм, окрім російсько-імперського, Пушкін різко засуджував: “Любов до Батьківщини в душі поляка завжди була почуттям безнадійно-похмурим. Пригадайте їхнього поета Міцкевича...”22. При цьому він був зовсім не наївною людиною та добре розумів, що й інші народи мають кожен свою Батьківщину. Але для Пушкіна існувало лише два патріотизми: або великодержавно-російський, або “неправильний”. Про це він проговорився в листі до С. Хитрово від 21 січня 1831 року, якраз у розпал Листопадового повстання поляків: “З-поміж усіх поляків мене цікавить лише Міцкевич. Він був у Римі на початку повстання. Боюсь, що він приїде до Варшави - бути присутнім при останніх корчах своєї Вітчизни"23.

Своєрідним “індикатором" ставлення всіх трьох поетів до російського абсолютизму є оцінка ними Петербурга як “урбаністичної емблеми” Російської імперії, а також до образу іï фундатора - Петра I. Глибоко символічно, що саме в день приїзду Міцкевича (07.11.1824) Петербург, зведений примхою Петра I та ціною життів сотень тисяч фактично рабів (у т. ч. українців і поляків) на малопридатних для життя фінських болотах, пережив жахливу повінь. Розбурхані води Неви, сягаючи другого поверху, знищили сотні будинків і вбили тисячі людей. Міцкевич побачив у цьому знак Долі: як не вічними виявилися зовні могутні будівлі імперської столиці, так само не вічною $є$ й сама ця імперія. Вільнолюбний поляк (“кичливый лях”, за висловом Пушкіна) різко засудив деспотизм та пиху Петра I: “...Російської... столиці де начала? / Чом захотілось цій державі йти, / Залазити в болотяні кути, / Що їх вона в чухонців одібрала? / Земля тут не для житла, а для лоз / Розкинулась, шумлять сніги та сльоти, / У кліматі мінливі ці широти, / Як настрій деспота - жара й мороз. / Та цар собі сподобав трясовицю / Болотисту і наказав звести / Не місто людям, а собі столицю, / Явив свою могуть на всі світи" (Дзяди). Побачивши промовисту невідповідність між, з одного боку, болотом, тобто відсутністю твердої основи для фундаменту, i, з другого боку, гранітною громадою будівель Петербурга (сама доставка каменю вимагала астрономічних коштів), поляк миттєво провидів паразитичну сутність усієї Росії: “Щоб ці палати возвелись. / Падлючі слуги і царі-тирани / Пролляли сліз і крові океани; / Щоб камені звезти для цих будов, / Скільки придумано таємних змов, / Скільки невинних вигнано, чи вбито, / Скільки зграбовано несамовито / Країв - щоб закупити все, що $\epsilon$ - / В Парижах, в Лондонах - ну що там ціни! - / За кров Литви, за сльози Украӥни, / За злото Польщі-все до-

\footnotetext{
22 А. С. Пушкин, Собрание сочинений: в 10 т., т. 7, Москва 1964, с. 306.

23 [źródło internetowe:] http://pushkin-lit.ru/pushkin/articles/cyavlovskij/mickevich.htm
} [Dostęp 03.05.2019]. 
бро сіє / Збудовано, возведено чертоги, / Вином шампанським вимито підлоги" 24 .

Шевченко теж украй негативно сприймав Петербург, зведений на болотяній трясовині (“з калюжі”) ціною чисельних людських жертв: “... От пішов я / Город озирати. / Там ніч, як день. Дивлюся: / Палати, палати / Понад тихою рікою; / А берег ушитий / Увесь каменем. Дивуюсь, / Мов несамовитий! / Як-то воно зробилося / 3 калюжі такої / Таке диво?.. Отут крові / Пролито людської - I без ножа..." (Сон, 1844).

Але якраз те, що обурювало Міикевича й Шевченка, приводило в захват Пушкіна: “Люблю тебя, Петра творенье / Люблю твой строгий, стройный вид / Невы державное теченье, / Береговой её гранит... / Люблю, военная столица, / Твоей твердыни дым и гром, / Когда полнощная царица / Дарует сына в царский дом, / Или победу над врагом / Россия снова торжествует...” або: “Красуйся, град Петров, и стой / Неколебимо, как Россия..." (Медный всадник, 1833). Існує думка, що ці рядки Пушкін писав як своєрідну полемічну відповідь на вірші Міцкевича, де поляк (після розгрому Листопадового постання 1831 р.) дав украй відверту й гостро негативну оцінку і Петербургу, і всій Росії як “імперії зла".

Своєрідним "семантичним ядром" ідеологеми імперської величі Роciї $є$ петербурзький пам'ятник Петру I, що в ньому символічним $є$ буквально все: і величезний гранітний моноліт, що його вручну (sic!), хоч були інші засоби, тягли сотні рабів (таким був наказ Катерини II, а накази деспотів не обговорюються); і розчавлена копитом коня гадюка (символ жорстокого придушення царатом будь-якого спротиву); і напис "PETRO primo CATHARINA secunda" ("ПЕТРУ Першому КАТЕРИНА Друга”), як натяк на тяглість російських імперських амбіцій... Невипадково про цей пам'ятник писали всі три поети: “Тут першому цареві будувала / Цариця друга пам'ятник, - пише Міцкевич, - Вже цар / Зі спижу литий велетень-моцар, / На бронзового всівшись буцефала, / Ждав, де б йому податись на коні, / Бо рідні замалі царю простори, / Тож послано по грунт йому за море, / На фінські узбережжя кам'яні. / Там горб гранітний вирвано з відроги / Гори, / і він пливе, біжить мерщій, / Покірно падає цариці в ноги, / Як раб, готовий послужити їй...”. Проте непохитність монумента $є$ хисткою: “....Над пропастю кінь вгору зніс копита, / Кінчається їзда несамовита - / I кінь, і цар в безодню вже летять... / Летять, немов замерзлий водоспад, / Немов з гранітів складений каскад, / Що, скутий льодом, над проваллям висне; / Та, як свободи сонце нам заблисне, / Як теплий вітер з Заходу повіє - / Що станеться з каскадом тиранії?”25.

24 До 200-річчя з дня народження Адама Мічкевича, пер. Д. Павличко, “Бюлетень Державного комітету України у справах національностей та міграції, Київ 1998, с. 40.

25 Там само, с. 37. 
Тарас Шевченко теж сприймав цей пам’ятник украй негативно: “... От я повертаюсь - / Аж кінь летить, копитами / Скелю розбиває! / А на коні сидить охляп, / У свиті - не свиті, / I без шапки. Якимсь листом / Голова повита. / Кінь басує — от-от річку, / От... от... перескочить. / А він руку простягає, / Мов світ увесь хоче / Загарбати. Хто ж це такий? / От собі й читаю, / Що на скелі наковано: / Первому — вторая / Таке диво наставила. / Тепер же я знаю: / Це той первий, що розпинав / Нашу Україну, / А вторая доконала / Вдову сиротину. / Кати! кати! людоїди! / Наїлись обоє, / Накралися; а що взяли / На той світ з собою?” (Сон, 1844). Отже, щодо пам’ятника Петру I Міцкевичева й Шевченкова “правди” теж різко контрастують із “правдою” Пушкіна.

...Проте, якби не Листопадове повстання, можливо, Міцкевич і Пушкін, хай навіть розділені державними кордонами, так і залишилися б приятелями, листуючись і обмінюючись творами, як згодом Міцкевич із Шевченком. Але іноді надходять “моменти істини", коли деякі раніше дипломатично обійдені питання постають руба, вимагаючи негайної та однозначної відповіді (наприклад, нині в Україні таким, сказати б, “символом віри” є питання: “то кому по праву належить Крим: Україні чи Росії'?). Саме таким “моментом істини” і стало Листопадове повстання, остаточно зірвавши з Пушкіна маску “співця свободи”, з-під якої прозирнула гримаса великодержавного шовініста. Волелюбний порив поляків він сприйняв як злочин проти Росії (“заколот Литви”) і був готовий нищити поляків збройно: “...Наші польські справи рухаються, дякувати Богові: Варшава оточена, Крженецького змістити нетерплячі патріоти, пише Пушкін до П. В'яземського 14.08.1831. - Крженецького бунтівники звинуватили в бездіяльності. Отже, вони хочуть битви; отже, вони будуть розбиті... Якщо завариться загальна Європейська війна, то, мабуть, шкодуватиму про своє одруження, хіба щзо візьму жінку до багажу"ге.

Зі згаданою вже своєю приятелькою Єлизаветою Хитрово, донькою Михайла Кутузова (російського “опонента” Наполеона Бонапарта в 1812 р.), Пушкін ще відвертіший: "Чи відомі Вам разючі слова фельдмаршала, Вашого татуся? Під час його вступу до Вільно поляки кинулися йому до ніг. “Встаньте, - сказав він їм, - пам'ятайте, що ви росіяни”... Ми можемо лише жаліти поляків. Ми надто сильні для того, щоб ненавидіти їх, війна, що починається, буде війною до винищення - або, принаймні, повинна бути такою...") 27.

Здавалося б, парадокс: “опальний і вільнолюбний” поет Пушкін повністю поділяє позицію офіційного придворного історика Миколи Карамзіна, висловлену останнім у листі до Олександра I: "Поляки, законом

26 А. С. Пушкин, Полное собрание сочинений: в 17 т., т. 14, Москва 1941, с. 208.

27 Там само, c. 420. 
утверджені в статусі окремого, державного народу, для нас небезпечніші за поляків-росіян"28. Проте насправді це аж ніяк не парадокс. До Пушкіна добре надається характеристика, що ії дав Адам Сжи Чарторийський Олександрові I: “ІІмператор любить зовнішні форми свободи, як люблять виставу... У душі імператора мирно співіснували і теоретична любов до людства, і практичне презирство до людей"29. Так само в душі Пушкіна мирно співіснували теоретична любов до свободи із практичною готовністю вбивати бориів за неї, передовсім - не росіян. Оце і $є$ та "правда" Пушкіна, яка повністю влаштовувала і влаштовує Російську державу, хай як би вона модифікувалася й називалася...

Та найяскравіше великодержавний шовінізм і схильність до шантажу Пушкіна виявився у його вірші Наклепникам Росії (16.08.1831), адресованому депутатам французького Парламенту, котрі закликали Європу втрутитися в російсько-польську війну на боці поляків ${ }^{30}$ : “....Ви грізні на словах - тож спробуйте на ділі! / Чи богатир старий вже підупав на силі, / Щоб ізмаїльського багнета загвинтить? / Чи руського царя не коряться вже слову? / Європу не здолаєм знову? / Забули, ворогів як бить? // Чи мало нас? Хіба від Пермі до Тавриди, / Від зимних фінських скель до спечної Колхіди, / Від збуреного раз Кремля / Аж по Китаю вічні стіни / В огні сталевої щетини / Не встане Руська вся земля?.." (переклад М. Стріхи).

Порівняння безлічі сталевих багнетів зі щетинками хижака (“російського ведмедя"?) є художньо влучним і погрозливим водночас ${ }^{31}$, та

\footnotetext{
28 В. Муравьев, Николай Карамзин, Москва 2005, с. 558.

29 В. И. Федорченко, Российская империя в лицах. Императорский дом. Выдающиеся сановники: Энииклопедия биографий: в 2 т., т. I, Красноярск - Москва 2000, с. 20.

30 "Протягом десяти місяців Польського повстання у французькій палаті депутатів точилися напружені дебати щодо політики Франції в російсько-польському конфлікті. Ліберальна частина палати... вимагала втручання у військові дії на боці Польщі. Було створено Комітет з надання допомоги повсталим полякам на чолі з Лафайєтом. До нього увійшли Гюго, Беранже, Барб'є, Жульєн, Делавіль, Давид. У Австрії за підтримку повсталих виступав Кошут, в Німеччині - Берне і Гайне. Оце й були ті “наклепники Росії”, котрим адресований вірш Пушкіна. Саме цей вірш призвів до розриву його колишньої дружби з Міцкевичем” (Л. Фрізман). Детальніше див.: Ю. Ковбасенко, Адам Мічкевич i Віктор Гюго vs Олександр Пушкін і Микола I, або Сучасний погляд на розв'язку однієї «дружби-ворожнечі», [в:] “Всесвіт” 2016, № 9-10, с. 250-253.

31 Росія ще й сьогодні доволі могутня, спроможна, за висловом Пушкіна, “встати в огні сталевої (і навіть ядерної) щетини”. А російська поезія-шантаж триває століттями. Окрім уже згаданих пушкінських віршів Клеветникам России (1831) або Олександра Блока Скіфи (1918), до неї можна віднести також скандальний вірш Йосипа Бродського На незалежність України (1991). Здавалося б, яке діло емігранту-єврею до незалежності України та розпаду СРСР, який депортував його самого? Але ж ні, цей емігрант не просто засудив незалежність України, а й дав різку оцінку державницькій позиції Тараса Шевченка, протиставивши їй шовіністичну позицію Пушкіна (“Александра”): “...С Богом,
} 
й фінал вірша звучить як відвертий шантаж: якщо європейці вступляться за Польщу, то загинуть так само, як свого часу загинули наполеонівські вояки: “...Хай, речники (в оригіналі “витии” (теревені), що значно дошкульніше. - Ю. К.), ваш гнів огніє / Й веде полки ворожих сил: / Їм місце є в полях Росії / Між нечужих для них могил". А звірства російських карателів у Польщі Пушкін тлумачить як внутрішню, “домашню" справу Росії: “...Се ж бо пря слов”ян поміж собою, / Домашня давня пря, вже зважена добою, / Питання, що його розв'яжете не ви..." // Віддавна вже поміж собою / Сі ворогують племена; / Не раз хилилась під грозою / I їхня, й наша сторона. / Бундючний лях впаде в покорі, / Чи вірний рос поляже в ніч? / Слов'янські всі струмки зіллються в руськім морі? / Воно зміліє? В цьому річ...”32. Отже, за всіх художніх принад, вірш Наклепникам Росії є і кон'юнктурним, і шовіністичним, і сервільним щодо Миколи I, який його замовив, схвалив і сприяв негайному опублікуванню ${ }^{33}$.

Вірш Пушкіна розколов російське суспільство на два протилежних табори: ретрогради (Микола I, Бенкендорф, Сергій Уваров та ін.) його хвалили, а ліберали (Микола Добролюбов, Петро В'яземський та ін.) лаяли. "Варто було Пушкіну написати два-три вірнопідданських вірша, писав згодом Бєлінський передовсім про цю поезію, - аби раптом утратити народну любов" 34 . Та найдошкульніше висловився В'яземський,

орлы, казаки, гетманы, вертухаи! / Только когда придет и вам помирать, бугаи, / Будете вы хрипеть, царапая край матраса, / Строчки из Александра, а не брехню Тараса" [Інтернет посилання:] https://podrobnosti.ua/2027823-skandalnoe-stihotvorenie-brodskogo-ob-ukraineokazalos-pravdoj-video.html [доступ: 03.05.2019].

32 Останні рядки - це відлуння сумновідомого російського мессіанства, натяку на якусь, буцімто, особливу, “рятівну стосовно себе та інших" роль Росії. Воно було ферментом Пушкінського світогляду: "Це Росія, це її неозорі простори проковтнули монгольське нашестя. Татари не наважилися перейти наших західних кордонів і залишити нас у тилу. Вони відійшли до своїх пустель, і християнська цивілізація була врятована. ...Нашим мучеництвом розвиток католицької Європи позбавився всіх перешкод”. Але історичні факти спростовують ці мессіанські візію та патетику. Монголів зупиняв Київ, а не Московія, яка набрала сили аж через століття після героїчної оборони Києва від орд Батия (1242). Та хіба доводиться дивуватися мессіанству Пушкіна в XIX ст., коли вже в XXI ст. Росію називають “единственным гарантом сохранения славянства в этом мире”, причому, це стверджує не росіянин, а білорус, див.: Я. И. Трещенок, Михаил Осипович Коялович и его время, Минск 1997, с. 677.

33 Позиція, яку зайняв Пушкін стосовно повсталої Польщі і тих західних письменників і політиків, котрі хотіли їй допомогти, і з найбільшою силою і визначеністю втілена в цьому вірші, повністю збігалася з позицією Миколи I. Існує мемуарне свідчення, що вірша було написано “на побажання государя". 5 вересня Пушкін читав його членам імператорської родини, 7-го було підписано цензурний дозвіл, а 14-го брошура надійшла в продаж. Така швидкість може бути пояснена лише волею царя” [Ю. Лебедев, “Клеветникам России” А. С. Пушкина, “Литература в школе” 2010, № 5, с. 11].

34 В. Г. Белинский, Лист від 15.03.1847, [в:] Той самий, Литературное наследство, т. II, Москва 1950, с. 571-581. 
презирливо назвавши цей вірш “шинельною одою”: “Пушкін у своєму вірші Наклепникам Росї скрутив їм (“наклепникам”. - Ю. К.) дулю в кишені. Він знає, що вони не прочитають його вірша, отже, не будуть відповідати на ті запитання, на які відповісти було б дуже легко, і навіть самому Пушкіну. За що Європі, що відроджується, любити нас?.. Ми гальмо в русі народів до поступового вдосконалення, морального і політичного. Ми поза Європою, що відроджується, і водночас тяжіємо над нею. "Народні речники", якби в них вийшло якось дізнатися про вірші Пушкіна і про високість таланту його, могли б відповісти йому коротко і ясно: ми ненавидимо, або, краще, ми зневажаємо Вас, оскільки в Росії поетові, як Ви, не соромно писати і друкувати вірші, схожі на Ваші... Невже Пушкін не переконався, що нам з Свропою воювати було би смертю. Для чого ж верзти нісенітницю, та ще й проти совісті, а понад усе - без користі?" 35 .

Проте вірш Наклепникам Росії за кордоном таки прочитали і дали на нього гідну відповідь, що нею стала вже згадана поезія Міцкевича До приятелів Москалів. У ній Пушкіна (не називаючи імені) звинувачено в сервільності та підлабузництві перед Миколою I: "Хтось інший, може, 3 вас покараний надміру; / Хтось чином, орденом зганьбив своє ім'я / I $з$ милості царя запродав душу щиру, / I перед деспотом низькі поклони б' $\epsilon^{36}$. // А, може, славите його тріумфи грізні, / За приятелями шкодуєте тихцем, / Рікою кров мою ллєте в моїй Вітчизні, / 3 проклять хизуючись перед своїм царем" (пер. Вс. Ткаченка). Пушкін добре зрозумів, кому адресовані докори колишнього польського приятеля, оскільки натяки на “милість царя" (камер-юнкерство), на “низькі поклони” перед деспотом, на засудження учасників Листопадового постання та уславлення російських карателів із корпусу Івана Паскевича, погрози “наклепникам Росії” тощо, - усе це місця для сумніву не залишало. Тож гарячкуватий нащадок африканців зразу кинувся писати “відповідь на відповідь”. Так з'явився незавершений вірш Он между нами жил... Та Пушкін його не

35 “Мені так вже набридли ці географічні фанфаронади наші, - пише П. В'яземський, - “Від Пермі до Тавриди” тощо. Що ж тут гарного, чому радіти і чим хизуватися, що ми лежимо врозтяжку, що в нас від думки до думки п'ять тисяч верст, що фізична Росія Федора, а моральна - дурепа (рос.: “Федора"/”дура”)... “Ви грізні на словах - тож спробуйте на ділі!” А це нагадує Яшку, котрий горлопанить на мирській східці: та що ви, ану суньтеся! та де вам, та ми ж!”, див.: Пушкин в воспоминаниях современников, т. 1, Москва 1985 , c. $149-150$.

36 Пор. $з$ публікацією в “Северной пчеле” (11.03.1830), де Пушкіна зображено як поета, котрий “кидає рими в усе священне, чваниться перед черню вільнодумством, а сам нишком плазує біля ніг сильних, аби ті дозволили йому вирядитися в шитий кафтан (чи не натяк на, знову-таки, сумнозвісну камер-юнкерську ліврею? - Ю. К.)” [Ю. Лотман, цит. праця, с. 173]. 
надрукував. Чому? Це питання, що досі чекає на об’єктивного дослідника, а наша розвідка добігає кінця.

\section{Таким чином, можна зробити висновки:}

1. Попри певну схожість життєвих і творчих шляхів, а також наявність непересічного поетичного хисту в усіх трьох поетів, А. Міцкевич i Т. Шевченко є “центральними авторами” (Г. Блум) відповідно польського і українського літературних канонів, натомість О. Пушкін в російському каноні займає одне з чільних, проте не центральне місце.

2. Поляк і українець вважаються центральними постатями відповідно польського і українського літературних канонів як у власних країнах, так і за їхніми кордонами. Натомість Пушкін є центром офіціозного канону в самій Росії ${ }^{37}$, але в світі “центральними авторами" російського літературного канону вважаються швидше Микола Гоголь, Лев Толстой і Федір Достоєвський ${ }^{38}$.

3. Кожен із трьох національних геніїв обстоював свою правду, власну ідейно-естетичну позицію, та існує одна непроминальна істина: якщо митець хоче, щоб його пам'ятники стояли на чужих землях і до них “не зарастала народная тропа" (О. Пушкін), йому необхідно поважати право націй на самовизначення та не зневажати патріотичних почуттів жодного $з$ народів. Адже кожен із цих народів має повне право сказати всьому світу словами Тараса Шевченка: “В своїй хаті - своя й правда!..”.

I насамкінець.

Навряд чи схочуть “слов'янські всі струмки зливатись в руськім морі". А це означає, що, на відміну від дискредитованої Пуикінської “правди”, “правда Міцкевича" $i$ “правда Шевченка” таки ближчі до Iстини. Отже, закономірність вимальовується така: монумент Поетові (як метафоричний, у пам'яті нащадків, так і реальний, із каменю) стоя-

\footnotetext{
37 Від сакраментального “Пушкин - это наше всё”! до офіційного затвердження в РФ (1997) т. зв. "Пушкінського дня Росії” [Інтернет посилання:] https://www.calend.ru/ holidays/0/0/52/, [доступ: 10.09.2019].

38 Звісно, певні невідповідності рецепції та оцінки творчого доробку письменника, 3 одного боку, на його батьківщині, та, з другого боку, за ії кордонами, не $\epsilon$ чимось унікальним. Так, Віктора Гюго (в інтерпретації Пушкіна - одного з “наклепників Росії”) французи вважають передовсім великим поетом, а в світі його сприймають насамперед як романіста. Проте випадок із Пушкіном особливий. Той факт, що росіяни позиціонують саме його (а не значно відоміших у світі М. Гоголя, Л. Толстого чи Ф. Достоєвського) як центральну постать російського літературного канону, засвідчує потужну офіціозну ідеологізацію його особистості та творчості, оскільки сяйво його таланту зручно використовувати як блискучу ширму, що прикриває шпарини самопроголошеного мессіанського проекту під назвою "русский мир”. І слід визнати щиро, що для такого вжитку свого творчого доробку та іміджу Пушкін підстави таки дав, оскільки, за всього свого безумовного поетичного таланту, сповідував і активно підтримував ідеологію російського імперіалізму та великодержавного шовінізму.
} 
тиме “довше, ніж мідь дзвінка” лише в тому випадку, коли Поет “в житті ніколи неправді не служив" ${ }^{\prime 2}$...

\section{БІБЛІОГРАФІЯ}

Âstrun Mečislav. 2008. Mickevič. Per. Andruhìv. D. Kiïv: Vidavnictvo S. Župans'kogo [Яструн Мечислав. 2008. Мічкевич. Пер. Андрухів. Д. Київ: Видавництво С. Жупанського].

Blum Garold. 2007. Zahidnij kanon: knigi na tlì epoh. Per. Semkìv R. Kï̈v: Fakt [Блум Гаролд. 2007. Західний канон: книги на тлі епох. Пер. Семківа Р. Київ: Факт].

Do 200-riččâ z dnâ narodžennâ Adama Mìckeviča. 1998. Kiïv: Bûleten' Deržavnogo komìtetu Ukraïniu spravah nacìonal'nostej ta mìgraciï [До 200-річчя з дня народження Адама Мічкевича. 1998. Київ: Бюлетень Державного комітету України у справах національностей та міграції].

Lebedev Ûrij. 2010. "Klevetnikam Rossii" A. S. Puškina. "Literatura v škole"nr 5: 1016 [Лебедев Юрий. 2010. “Клеветникам России» А. С. Пушкина. “Литература в школе" № 5: 10-16].

Lotman Ûrij. 1982. Aleksandr Sergeevič Puškin. Biografiâ pisatelâ. Leningrad: Prosveŝenie [Лотман Юрий. 1982. Александр Сергеевич Пушкин. Биография писателя. Ленинград: Просвещение].

Šapovalov Mihail. 2014. Puškin i pan Adam. "Naš sovremennik" № 6: 265-271 [Шаповалов Михаил. 2014. Пушкин и пан Адам. "Наш современник” № $6: 265-271]$.

Ševčenkìvs'ka enciklopediâ. V 6 tomah. 2015. Tom 5. Red. Žulins'kij M. Kiïv: Ìnstitut lìteraturi ìm. T. G. Ševčenka Nacìnal'noï akademiï nauk Ukraïni: 396-398 [Шевченківська енциклопедія. В 6 томах. 2015. Том 5. Ред. Жулинський М. Київ: Інститут літератури ім. Т. Г. Шевченка Національної академії наук України: 396-398].

Slìď̌o-naglâdovì spravi Tarasa Ševčenka. Korpus dokumentìv(1847-1859). Metagrafovanì teksti. 2018. Red. kol.: Boron' O., Borâk G., Burlaka G., Gal'čenko S., Gliz' İ., Žulins'kij M., Muzičuk O., Reênt O., Smolìj V. (vìdp. red.), Stus D., Šandra V. Kiïv: Arìj [Слідчо-наглядові справи Тараса Шевченка. Корпус документів (1847-1859). Метаграфовані тексти. 2018. Ред. кол.: Боронь О., Боряк Г., Бурлака Г., Гальченко С., Глизь І., Жулинський М., Музичук О., Реєнт О., Смолій В. (відп. ред.), Стус Д., Шандра В. Київ: Арій].

Spogadi pro Tarasa Ševčenka. 1982. Kï̈v: Dnìpro [Спогади про Тараса Шевченка. 1982. Київ: Дніпро].

Strìha Maksim. 2017. Ulûblenì perekladi. Kiïv: Penmen: 703-707 [Стріха Максим. 2017. Улюблені переклади. Київ: Пенмен: 703-707].

\section{ADAM MICKIEWICZ, ALEXANDER PUSHKIN, TARAS SHEVCHENKO: VISION OF NATIONAL IDENTITY, PLACE IN THE LITERATURE CANON}

Sumary. The article considers the key moments of the life and creative path of the three central figures of Slavonic literatures: Adam Mickiewicz (Poland), Alexander Pushkin

39 Це пряма цитата з вірша Максима Рильського, який є відлунням Горацієвого Exegi monumentum. Ну, а аналіз вірша Адама Міцкевича Exegi munimentum ... може стати предметом окремого наукового дослідження. 
(Russia) and Taras Shevchenko (Ukraine). The emphasis is on the fundamentally (and often little-known) parameters of their outlook and creativity, in particular on its statebuilding potential, which was thoroughly retouched by literary scholars of the USSR and socialist countries. In particular, it was concluded that A. Mickiewicz and T. Shevchenko were central to the works of art in the Polish and Ukrainian literary canons, as well as certain "ideological preferences" in the case of "canonization" of O. Pushkin's work in Russia.

Key words: canonical literary; historical memory; national identity; functions of fiction.

\section{ADAM MICKIEWICZ, ALEKSANDER PUSZKIN, TARAS SZEWCZENKO: WIZJA TOŻSAMOŚCI NARODOWEJ, MIEJSCE W KANONIE LITERACKIM}

Streszczenie. W niniejszym artykule autor analizuje kluczowe momenty w biografii oraz twórczości trzech centralnych postaci literatur słowiańskich: Adama Mickiewicza (Polska), Aleksandra Puszkina (Rosja) i Tarasa Szewczenki (Ukraina). Uwaga badacza skupia się wokół zasadniczych konceptualnych (najczęściej mało znanych) kwestii światopoglądu i twórczości wspomnianych twórców, a zwłaszcza - na wizji tożsamości narodowej i/lub państwowej, którą gruntownemu retuszowi poddawali literaturoznawcy z ZSRR i innych krajów socjalistycznych. Autor podkreśla fakt, że o ile twórczość Mickiewicza i Szewczenki zajmuje centralne miejsce w polskim i ukraińskim kanonie literackim, to twórczość Puszkina charakteryzuje się „określonymi preferencjami” „kanonizowania” w literaturoznawstwie rosyjskim.

Slowa kluczowe: kanon literacki, pamięć historyczna, tożsamość narodowa, funkcje literatury pięknej. 